Acta vet. scand. $1964,5,24-34$.

From the Department of Medicine, Royal Veterinary College, Stockholm, Sweden.

\title{
VOLUME OF DISTRIBUTION OF TRITIATED WATER AS A MEASURE OF TOTAL BODY WATER IN SUCKLING PIGS*)
}

\author{
By \\ Gunnar Tollerz
}

Pigs are not seldom exposed to factors which tend to disturb their water-balance. This is especially true for suckling pigs. Enteritis with diarrhoea is very common at this age and frequently causes death. The carcasses of such pigs may show changes that indicate dehydration. A seriously disturbed water-balance may therefore substantially contribute to the heavy losses in piglet raising.

In a previous work (7) the extracellular water volume was determined by the thiosulphate method at different ages of healthy suckling pigs.

In-vivo determination of total body water (TBW) in pigs weighing $29-155 \mathrm{~kg}$, was made by Kraybill et al. (2) by the antipyrine method (5). Up to now no determinations in living baby pigs seem to have been performed.

In the work presented here TBW was determined with tritiated water (HTO) by Langham's method (3), partly modified in order to be more suitable for piglets with small blood-volumes.

\section{MATERIAL AND METHODS}

Experimental animals. Four litters of piglets of the Swedish Landrace were used. Litter A, 11 pigs, were followed through repeated TBW determinations. Litters $B, C$, and $D$ were used for

*) Supported by grants from Anslag för främjande av medicinsk forskning vid Veterinärhögskolan. 
additional experiments as will be stated later. During the time of the experiment the pigs were kept together with the sow. At the age of 2 days and again at about 3 weeks, each pig was given $2 \mathrm{ml}$. of an iron-dextran preparation intramuscularly ("Imposil", Pharmacia, Uppsala), corresponding to $150 \mathrm{mg}$. of $\mathrm{Fe}^{+++}$. When they were 3 weeks old, a commercial solid food for young pigs (Smågrisfoder, Fors) was given ad lib. in a separate pen to which only the piglets had entrance. All pigs appeared healthy during the experimental period. Mean weight at farrowing was $1.34 \mathrm{~kg}$ and at 42 days of age $9.51 \mathrm{~kg}$.

Experimental procedure. The pigs were starved and thirsted for 3 hours and then anaesthetized by inhalation of trichlorethylene. A 5-ml. blood specimen for blank determination was taken from the anterior vena cava at the thoracic aperture in a tube containing 3 standardized drops of $1 \%$ heparin. About 0.2 mC tritium as HTO (Radiochemical Center, Amersham, England) per $\mathrm{kg}$ body-weight, dissolved in isotonic sodium-chloride solution to a volume between 4 and $15 \mathrm{ml}$., the smaller volumes used for younger pigs, was. injected intraperitoneally with carefully calibrated syringes.

Another 5-ml. blood specimen was taken about 11/2 hours later in the same way as the first one. No food or water was given to the pig in the meantime.

The pigs were weighed before and after the experiment with an accuracy of $\pm 5 \mathrm{~g}$. The initial weights were used in the calculations. The piglets in litter A were preliminarly divided into two groups $(6+5$ piglets $)$. The mean body-weights of the groups were 1.346 and $1.330 \mathrm{~kg}$., respectively. The grouping was done partly because 5 or 6 pigs are a convenient number for one set of determinations. Further, by alternating determination of TBW in the groups, the number of examinations for an individual pig could be limited (Fig. 1 and Table 1). At the age of 34 and 42 days this grouping was not used because the bowel, notably the colon spiral, is well filled at this time. The intraperitoneal injection can inadvertently be made in the bowel. If this should happen, the remaining number of animals in the group might be too small.

In the series of experiments the TBW was determined 50 times. Three experiments had to be discarded for various reasons. Additional duplicate determinations were performed in 8 piglets (litter B), so that the second determination was made just after 


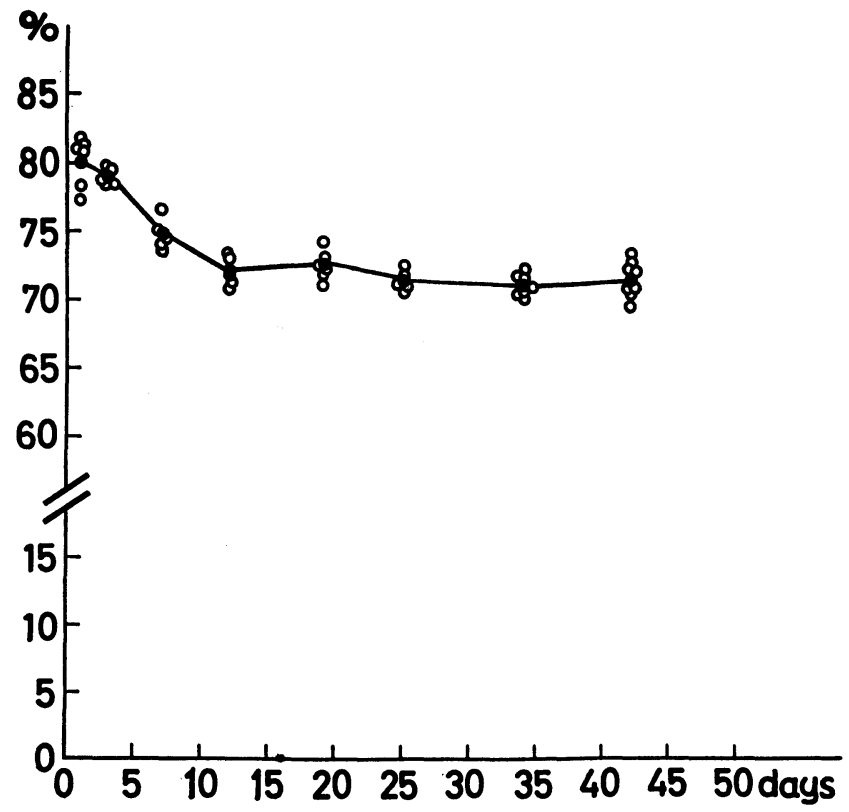

F i g. 1. Total body water as percentage of the body-weight (vertical axis) of one litter of suckling pigs. The age of the piglets is depicted on the horizontal axis.

T a b l e 1

Results of 47 determinations of the total body water in 11 piglets.

\begin{tabular}{ccccc}
\hline & & & \multicolumn{2}{c}{ TBW } \\
\cline { 4 - 5 } $\begin{array}{c}\text { Pig } \\
\text { no }\end{array}$ & $\begin{array}{c}\text { age } \\
\text { days }\end{array}$ & $\begin{array}{c}\text { weight } \\
\text { kg }\end{array}$ & $\begin{array}{c}\text { volume } \\
\text { (litre) }\end{array}$ & $\begin{array}{c}\text { \% of body- } \\
\text { weight }\end{array}$ \\
\hline 1 & 1 & 1.38 & 1.13 & 81.7 \\
& 7 & 2.43 & 1.81 & 74.6 \\
2 & 19 & 4.62 & 3.28 & 71.1 \\
& 1 & 1.61 & 1.25 & 77.3 \\
& 7 & 2.58 & 1.91 & 73.9 \\
& 19 & 4.50 & 3.24 & 72.0 \\
3 & 34 & 9.19 & 6.60 & 71.9 \\
& 42 & 11.28 & 8.22 & 72.8 \\
& 1 & 1.26 & 0.99 & 78.3 \\
4 & 7 & 1.95 & 1.47 & 75.2 \\
& 19 & 3.52 & 2.58 & 73.3 \\
& 42 & 8.57 & 6.00 & 70.1 \\
& 1 & 1.42 & 1.15 & 80.9 \\
& 19 & 4.31 & 3.13 & 72.6 \\
& 34 & 8.20 & 5.84 & 71.2 \\
& 42 & 9.50 & 6.98 & 73.5
\end{tabular}


Table 1 (continued)

\begin{tabular}{|c|c|c|c|c|}
\hline \multirow[b]{2}{*}{$\begin{array}{r}\text { Pig } \\
\text { no }\end{array}$} & \multirow[b]{2}{*}{$\begin{array}{c}\text { age } \\
\text { days }\end{array}$} & \multirow[b]{2}{*}{$\begin{array}{c}\text { weight } \\
\text { kg }\end{array}$} & \multicolumn{2}{|c|}{ TBW } \\
\hline & & & $\begin{array}{l}\text { volume } \\
\text { (litre) }\end{array}$ & $\begin{array}{l}\% \text { of body- } \\
\text { weight }\end{array}$ \\
\hline \multirow[t]{5}{*}{5} & 1 & 1.46 & 1.18 & 80.8 \\
\hline & 7 & 2.30 & 1.70 & 74.1 \\
\hline & 19 & 4.13 & 3.07 & 74.3 \\
\hline & 34 & 7.98 & 5.73 & 71.8 \\
\hline & 42 & 9.36 & 6.78 & 72.4 \\
\hline \multirow[t]{5}{*}{6} & 1 & 1.39 & 1.13 & 81.1 \\
\hline & 7 & 2.09 & 1.60 & 76.7 \\
\hline & 19 & 3.98 & 2.89 & 72.7 \\
\hline & 34 & 7.92 & 5.62 & 70.9 \\
\hline & 42 & 9.43 & 6.83 & 72.4 \\
\hline \multirow[t]{5}{*}{7} & $\mathbf{3}$ & 1.64 & 1.29 & 78.7 \\
\hline & 12 & 2.78 & 1.98 & 71.1 \\
\hline & 25 & 4.49 & 3.22 & 71.6 \\
\hline & 34 & 6.45 & 4.68 & 72.5 \\
\hline & 42 & 8.01 & 5.68 & 70.8 \\
\hline \multirow[t]{5}{*}{8} & 3 & 1.75 & 1.37 & 78.4 \\
\hline & 12 & 3.00 & 2.15 & 71.6 \\
\hline & 25 & 5.76 & 4.09 & 71.0 \\
\hline & 34 & 7.58 & 5.34 & 70.5 \\
\hline & 42 & 9.71 & 6.92 & 71.3 \\
\hline \multirow[t]{4}{*}{9} & 3 & 1.72 & 1.37 & 79.6 \\
\hline & 12 & 2.74 & 2.01 & 73.4 \\
\hline & 25 & 5.75 & 6.10 & 71.4 \\
\hline & 42 & 10.24 & 7.29 & 71.2 \\
\hline \multirow[t]{4}{*}{10} & 3 & 1.56 & 1.24 & 79.6 \\
\hline & 12 & 2.44 & 1.76 & 72.2 \\
\hline & 25 & 4.92 & 3.52 & 71.5 \\
\hline & 34 & 6.52 & 4.61 & 70.7 \\
\hline \multirow[t]{3}{*}{11} & 3 & 1.36 & 1.07 & 78.4 \\
\hline & 12 & 2.02 & 1.48 & 73.3 \\
\hline & 25 & 5.72 & 4.15 & 72.6 \\
\hline
\end{tabular}

the end of the first one. To determine the tritium level in blood after intraperitoneal injection, six 3 day old and six 40 day old pigs (litter $\mathrm{C}$ ) were followed for about 3 hours after the injection.

The possible influence of the mode of administration on the volume of distribution was tested in 22 pigs from 3 litters (litter $B, C$, and D). Half the litter was treated intravenously and the other half intraperitoneally. Each litter was examined on one occasion. In litter C ( 6 pigs) the pigs were 12 day old, in litter B, (8 pigs) 14 day, and in litter D (8 pigs) 21 day old. 
Two pigs were desiccated. One was taken by hysterectomy on the 112th day of pregnancy, i. e. about 2 days before normal delivery. The other pig was 3 day old. The soft tissues were ground and the bones were carefully crushed. Drying was done at a temperature of $80^{\circ} \mathrm{C}$ and an absolute pressure of about 100 $\mathrm{mm} \mathrm{Hg}$ until a constant weight was obtained.

Tritium analysis. The apparatus for counting the tritium activity was a Packard Tri-Carb $314 \mathrm{X}$ with counting chambre at $-8^{\circ} \mathrm{C}$. Counting time was 10 minutes. Photomultipler voltage was set at tap $8(1200 \mathrm{~V})$ and pulse height-discriminator at 10-100 Volts. 20-ml. vials, Packard Catalog no. 600.1015, were used. ${ }^{*}$ )

The blood specimen was centrifuged. $2 \mathrm{ml}$. of blood plasma were pipetted into a flask connected to a test tube by a glass tube. The flask was placed in a bath of liquid paraffin which was heated to $+130^{\circ} \mathrm{C}$. This temperature was maintained until a brownish mass of dry substance was obtained and no more water dripped into the test tube. The latter was kept in a water bath at about $+15^{\circ} \mathrm{C} .0 .2 \mathrm{ml}$. of the distillate was then mixed with $10 \mathrm{ml}$. of a scintillator solution $(700 \mathrm{ml}$. toluene, $300 \mathrm{ml} .99 .6 \%$ ethanol, and 5 g. 2.5-diphenyloxazole). The scintillator solution was prepared fresh each week. It was protected from daylight during storage and when used. The activity degree of the scintillator system was found to be $8.2 \%$.

Samples of the solution used for injection were diluted with distilled water so that roughly the same HTO concentration was obtained as in the distillate. From each distillate 4 determinations of radioactivity were made at the same time as 3 determinations on each of 2 dilutions of the injection solution. In this way the experiments were internally standardized. Every 10 th vial counted contained a standard solution with known number of counts per minute. Background coincidence and reagent blank were tested every time the Tri-Carb was used. The counting response was linear over the range encountered in the samples. The aim was not to obtain a quantitative distillation but to produce a destillate with the same concentration of tritium as in the original water. This was tested from water by 12 destillations of 2-ml. specimens

$\left.{ }^{\star}\right)$ The author expresses his appreciation to Professor $C$. G. Schmiterlöw for putting the technical facilities of the pharmacological department to his disposal. 
of a HTO dilution from which 8 vials with scintillator solution were prepared. From each distillate 4 vials were prepared as usual. The same thing from plasma was tested in 8 different plasmas, to which had been added 10 per cent by volume of a HTO solution. The concentrations of tritium in the distillate and before distillation were compared.

The error of the tritium-analysis method was calculated as follows. At one experiment sufficient blood was taken to obtain $20 \mathrm{ml}$. of plasma containing tritium. $102-\mathrm{ml}$. plasma specimens were distilled on different occasions. Other preparations, including the radioactivity determinations, were made on one occasion. The 10 distillations gave 10 107.1 \pm 74.1 (mean \pm S.D.) counts per minute. The standard error is $0.74 \%$ of the mean.

Calculation of $T B W$. The TBW was calculated by the formula $\mathrm{V}=\frac{\left(\mathrm{C}_{\mathrm{inj}}-\mathrm{C}_{\mathrm{R}}\right) \cdot \mathrm{a}}{\mathrm{C}_{\mathrm{t}}-\mathrm{C}_{\mathrm{o}}}$ where $\mathrm{V}$ is the volume of distribution of HTO in ml. and $C_{i n j}$ the number of counts per minute for the solution which is diluted a times. $C_{R}$ is the number of counts per minute for the reagent blank. $C_{o}$ and $C_{t}$ are the number of counts per minute for the plasma water of blood specimens taken before and 1/2 hours after the injection of HTO, respectively. Corrections were made for the adding of heparin and for errors of the syringes.

\section{RESULTS}

The tritium level. The tritium level of blood plasma after intraperitoneal injection of HTO was tested in six 3 day old and six 40 day old pigs. The level of tritium decreased by $0.72 \pm 0.56 \%$ from 1 hour to 3 hours after the injection. No difference between 3 day and 40 day old pigs could be found.

$T B W$. The results of the 47 determinations of the TBW measured as the $1 \frac{1}{2}$-hour distribution value after intraperitoneal injection of HTO are given in Fig. 1 and Table 1. TBW is $80.1 \%$ of the body-weight at 1 day of age, $72.7 \%$ at 19 days of age and $71.8 \%$ at 42 days of age.

Of the two desiccated pigs, the water content of the one taken by hysterectomy about 2 days before delivery was $81.4 \%$ and of the one normally delivered 3 day old $78.7 \%$ of the body-weight. Reproducibility. The reproducibility was tested in 8 cases by two consecutive determinations (Table 2). The mean decrease 
T a b l e 2

Results of two consecutive determinations of total body water in 8 piglets.

\begin{tabular}{|c|c|c|c|c|c|c|c|}
\hline \multirow[b]{2}{*}{$\begin{array}{l}\text { Pig } \\
\text { no }\end{array}$} & \multirow[b]{2}{*}{$\begin{array}{l}\text { age } \\
\text { days }\end{array}$} & \multirow[b]{2}{*}{$\begin{array}{c}\text { weight } \\
\text { kg }\end{array}$} & \multirow[b]{2}{*}{ difference } & \multicolumn{4}{|c|}{ TBW } \\
\hline & & & & $\begin{array}{l}\text { volume } \\
\text { litre }\end{array}$ & difference & $\begin{array}{c}\% \text { of } \\
\text { body-weigh }\end{array}$ & $\begin{array}{l}\text { difference } \\
\text { t }\end{array}$ \\
\hline 1 & 29 & 5.73 & & 4.15 & & 72.4 & \\
\hline & & 5.68 & -0.04 & & -0.01 & 72.8 & +0.4 \\
\hline 2 & 29 & 5.45 & & 3.91 & & 71.8 & \\
\hline & & 5.38 & -0.07 & 3.83 & -0.08 & 71.2 & -0.6 \\
\hline 3 & 29 & $\begin{array}{l}5.27 \\
5.19\end{array}$ & -0.08 & $\begin{array}{l}3.86 \\
3.69\end{array}$ & -0.17 & $\begin{array}{r}73.2 \\
71.1\end{array}$ & -2.1 \\
\hline 4 & 29 & $\begin{array}{l}3.86 \\
3.79\end{array}$ & -0.07 & $\begin{array}{l}2.86 \\
2.84\end{array}$ & -0.02 & $\begin{array}{r}74.1 \\
75.0\end{array}$ & +0.9 \\
\hline 5 & 35 & $\begin{array}{l}9.86 \\
9.79\end{array}$ & -0.08 & $\begin{array}{l}6.95 \\
6.75\end{array}$ & -0.20 & $\begin{array}{l}70.5 \\
69.0\end{array}$ & -1.5 \\
\hline 6 & 35 & $\begin{array}{l}7.48 \\
7.41\end{array}$ & -0.07 & $\begin{array}{l}5.38 \\
5.18\end{array}$ & -0.20 & $\begin{array}{r}71.9 \\
69.9\end{array}$ & -2.0 \\
\hline 7 & 35 & $\begin{array}{l}6.84 \\
6.78\end{array}$ & -0.06 & $\begin{array}{l}4.98 \\
4.91\end{array}$ & -0.07 & $\begin{array}{r}72.8 \\
72.5\end{array}$ & -0.3 \\
\hline 8 & 35 & $\begin{array}{l}6.31 \\
6.26\end{array}$ & -0.05 & $\begin{array}{l}4.63 \\
4.57\end{array}$ & -0.06 & $\begin{array}{r}73.3 \\
73.0\end{array}$ & -0.3 \\
\hline
\end{tabular}

of TBW in the second determination $1 \frac{1}{2}$ hour after the first one was $-0.70 \pm 1.11 \%$ of the body-weight. This standard deviation corresponds to $1.53 \%$ of the mean.

The method for distillation. The concentration of tritium after distillation of tritiated water is $99.9 \pm 0.7 \%$ of the concentration before distillation (13 samples).

The concentration of tritium after distillation of plasma containing tritium is $97.6 \pm 0.6 \%$ of the concentration in plasma (8 samples).

Intraperitoneal injection compared with intravenous injection. The route of administration of HTO was tested in 22 pigs from 
3 litters. The intravenous injection of HTO in 11 pigs gave mean $\mathrm{TBW}=74.5 \%$ of the body-weight (mean body-weight $=3.71$ kg., mean age $=16$ days). The intraperitoneal injection in 11 pigs gave mean TBW $=72.8 \%$ of the body-weight (mean body-weight $=3.75 \mathrm{~kg}$., mean age $=16$ days). The difference is significant $(t=3.56 ; 0.01>P>0.001)$.

\section{DISCUSSION}

The HTO method of Langham et al. (3) had to be modified to be applicable to baby pigs. Piglets contain about $8 \%$ blood, which in a $1 \frac{1}{2} \mathrm{~kg}$. pig makes $120 \mathrm{ml}$. The amount of blood available for analysis is therefore very limited. According to our observations, the tritium level decreased by $0.72 \%$ in the interval between 1 and 3 hours after an intraperitoneal injection. As no extraneous water was introduced during that time, the decrease should be due mainly to dilution with water produced from the metabolic processes or/and water from parts of the intestine where tritium balance had not yet been reached. By analysis of one blood specimen which is taken $1 \frac{1 / 2}{2}$ hours after the injection of HTO the volume of distribution at $1 \frac{1}{2}$ hours is obtained. It was calculated by extrapolation that this volume may be about $0.5 \%$ larger than the volume of distribution at zero time.

The advantage of the distillation procedure is that the plasma protein needs not be precipitated. Dilution of the plasma with a protein precipitator is therefore avoided. For precipitation of plasma proteins, trichloracetic acid is generally used. Trichloracetic acid acts as a quencher for the weak tritium beta radiation, however, and is unsuitable for that reason as well. For standardization of the solution to be injected it is necessary that a dilution of this solution is added to the plasma blank at each determination. To obtain sufficient reliability the quantity of blood needed could have to be so large that the use of the HTO method in piglets would be seriously limited. After distillation of the plasma, activity determination of the plasma water is made. Internal standardization is therefore done by dilution of the injection solution with water instead of plasma.

The distillation procedure does not seem to influence the concentration of tritium in HTO. In calculating the recovery from plasma the deplacement of protein must be taken into consideration. The protein-deplacement factor (apparent specific 
volume) has been determined to 0.730 for normal human serum (4). The corresponding factor for pig plasma is not known. The human serum factor was therefore used. The amount of protein was determined by the biuret method.

Other rapid assay procedures for tritium in body fluid have been published, one for rapid vacuum sublimation (8) and others including a preliminary distillation of the water with benzene (9) or copper-oxide (6). The advantages of the distillation procedure used in this work are that the apparatus is simple, has great capacity, and gives sufficient reliability.

The intraperitoneal route of administration is for practical reasons preferable. The explanation why the intraperitoneal injection gives lower values of TBW than intravenous injection is probably as follows. Even if the intravenous injection is made slowly it gives higher blood concentration of tritium initially. This causes greater elimination of tritium through the kidneys and the lungs before equilibrium is reached. The isotonic injection solution requires some time for absorption through the peritoneum. Of 3 pigs which received intraperitoneal injections the blood level of tritium had reached a maximum after 10 minutes in 2 but not in the third one. After $1 \frac{1 / 2}{2}$ hours the concentration in the blood is therefore higher with intraperitoneal injection, which means a smaller volume of distribution. As it can be assumed that absorption from the peritoneal cavity is complete (1) there is good reason to believe that the intraperitoneal injection gives a truer TBW value than does the intravenous injection.

Of 8 duplicate determinations (Table 2) the first series gave a mean TBW of $74.31 \%$ of the body-weight. The mean decrease in the second series of determinations was $0.70 \pm 1.11 \%$ of the body-weight. If the mean decrease of body-weight is assumed to be due entirely to loss of water from TBW during $1 \frac{1}{2}$ hours the time between the two determinations - the TBW would be expected to decrease by $0.51 \%$ of the body-weight. The small difference between this percentage and the found percentage for the mean decrease is within the limits of the error of the HTO method, even if a part of the mean body-weight decrease depends upon weight losses other than water. 


\section{REFERENCES}

1. Efskind, L.: Experimentelle Untersuchungen über die Biologie des Peritoneums. Det Norske Videnskaps-Adakemie Oslo, 1940. Del I och II.

2. Kraybill, H. F., Goode, E. R., Robertson, R. S. B., and Sloane, H. S.: In vivo measurement of body fat and body water in swine. J. Appl. Physiol., 1953, 6, 27.

3. Langham, W. H., Eversole, W. J., Hayes, F. N. and Trujillo, T. T.: Assay of tritium activity in body fluids with use of a liquid scintillation system. J. Lab. Clin. Med. 1956, 47, 819.

4. Van Slyke, D. D., Hiller, A., Philips, R. A., Hamilton, P. B., Dole, V. P., Archibald, R. M. and Eder, H. A.: The estimation of plasma protein concentration from plasma specific gravity. J. Biol. Chem. 1950, 183, 331.

5. Soberman, R., Brodie, B. B., Levy, B. B., Axelrod, J., Hollander, V. and Steele, J. M.: The use of antipyrine in the measurement of total body water in man. J. Biol. Chem. 1949, 179, 31.

6. Steel, G. G.: A simple method of estimating the tritium content of biological samples. Intern. J. Appl. Radit. 1960, 9, 94.

7. Tollerz, G.: The volume of distribution of sodium thiosulphate as a measurement of the extracellular fluid space in suckling pigs. Acta vet. scand. 1963, 4, 97.

8. Vaugan, B. E. and Boling, E. A.: Rapid assay procedures for tritium labeled water in body-fluids. J. Lab. Clin. Med. 1961, $57,159$.

9. Werbin, H., Chaikoff, J. L. and Imada, M. R.: Rapid sensitive method for determination $\mathrm{H}^{3}$ water in body-fluids by liquid scintillation spectrometry. Proc. Soc. Exp. Biol. Med. 1959, $102,8$.

\section{SUMMARY}

The total body water (TBW) was determined, using a method with tritiated water. One litter of 11 piglets was used for the experiment comprising repeated deterimnations during the first 6 weeks of life. The mean TBW defined as the $1 \frac{1 / 2}{2}$ hours distribution volume of tritium after intraperitoneal injection was found to decrease gradually from $80.1 \%$ of the body-weight at 1 day of age to $72.7 \%$ at 19 days of age and then remained fairly constant. A simple distillation technique for recovering the water from plasma was used. Small variations between pigs of the same age were found. The variations in individual pigs from time to time and the results of duplicate determinations seem reasonable. 


\section{ZUSAMMENFASSUNG}

Das totale Flüssigkeitsvolumen von säugenden Ferkeln definiert als das Verteilungsvolumen des Tritium-Wassers.

Es wurden Bestimmungen des totalen Flüssigkeitsvolumens mit einer modifizierten Tritiummethode durschgeführt. Ein Wurf von 11 säugenden Ferkeln wurde während der 6 ersten Lebenswochen wiederholt untersucht. Das totale Flüssigkeitsvolumen, definiert als das Verteilungsvolumen des Tritium 1/1/2 Stunden nach intraperitonealer Injektion vermindert sich allmählich von 80.1\% des Körpergewichtes im Alter von 1 Tag zu $72.7 \%$ im Alter von 19 Tagen und bleibt dann ungefähr konstant. Um das Wasser aus Plasma erhalten zu können, wurde ein einfaches Destillationsverfahren angewendet. Kleine Variationen zwischen Ferkeln im gleichen Alter wurden beobachtet. Die Variationen bei einzelnen Ferkeln im verschiedenen Alter und die Befunde zweier aufeinander folgenden Bestimmungen bei demselben Ferkel scheinen wahrscheinlich zu sein.

\section{SAMMANFATTNING}

Totala kroppsvattnet hos diande grisar mätt som distributionsvolymen av tritierat vatten.

Totalvattenbestämningar har utförts enligt en metod med tritierat vatten. En kull om 11 grisar undersöktes upprepade gånger under de 6 första levnadsveckorna. Totalvattenvolymen definierad som distributionsvolymen för tritium 11/2 timme efter intraperitoneal injektion avtog kontinuerligt från $80.1 \%$ av kroppsvikten vid 1 dags ålder till $72.7 \%$ vid 19 dagars ålder och höll sig sedan ganska konstant. För erhållande av vattnet från blodplasma användes en enkel destillationsteknik. Små variationer mellan lika gamla grisar kunde ses. Undersökningsresultaten vid olika åldrar för en och samma gris och resultaten av två bestämningar utförda efter varandra på samma gris synes rimliga. 